\title{
Chapter 33 \\ Article 32: The Right to Protection from \\ Economic Exploitation and Hazardous Activities
}

\author{
Gerison Lansdown
}

1. States Parties recognize the right of the child to be protected from economic exploitation and from performing any work that is likely to be hazardous or to interfere with the child's education, or to be harmful to the child's health or physical, mental, spiritual, moral or social development.

2. States Parties shall take legislative, administrative, social and educational measures to ensure the implementation of the present article. To this end, and having regard to the relevant provisions of other international instruments, States Parties shall in particular:

(a) Provide for a minimum age or minimum ages for admission to employment;

(b) Provide for appropriate regulation of the hours and conditions of employment;

(c) Provide for appropriate penalties or other sanctions to ensure the effective enforcement of the present article.

What Did Children Say?

'Governments should advertise more about children rights as well as make regular check-ups on homes and workplaces to ensure children are not doing child labour or unfairly paid.' (Latin America/Caribbean).

(continued)

G. Lansdown ( $\square)$

Carleton University, Ottawa, ON, Canada

Z. Vaghri et al. (eds.), Monitoring State Compliance with the UN Convention

on the Rights of the Child, Children's Well-Being: Indicators and Research 25,

https://doi.org/10.1007/978-3-030-84647-3_33 
'Schools holding public education initiatives by talking to parents about harmful work.' (Latin America/Caribbean).

We have to make sure that they are reliable statistics on working children. (Africa).

'Having an enforced documented minimum age where children can start working.' (Latin America/Caribbean).

\section{Overview}

Article 32 establishes the right of children to protection from economic exploitation, and from work deemed to be harmful to their health or detrimental to any dimension of their development, or which interferes with their education. It also identifies, in broad terms, the measures required by States Parties to achieve this protection. The development of the text during the drafting process moved from a focus on protection of the child towards an understanding of the right to protection in this context (Swepston, 2012, pp. 14-15).

However, after much debate, and influence from the ILO, the drafters agreed to rely on a general formulation of the standards necessary to provide appropriate protection. For example, prescribed minimum ages for work were removed in favour of a general requirement that States Parties introduce legislative age limits (Office of the United Nations High Commissioner for Human Rights and Rädda barnen (Society: Sweden), 2007, pp. 693-708). This approach was adopted in acknowledgement of the different levels of development between States Parties, as well as the importance of differentiating between the protections needed for different types of work. It was left to the Committee to provide subsequent interpretation, drawing on the more detailed provisions in ILO Conventions, 138 and 182 in particular, on the definitions of work, the nature of the regulatory environment needed, recommended age limits, and the nature of hazardous or harmful work.

The drafting process involved a gradual consensus that the purpose of Article 32 was to incorporate the issue within the Convention in the context of existing international law, notably standards established by the ILO, rather than seeking to adopt new protections (Swepston, 2012, p. 17). This approach is clearly envisioned in the reference in paragraph 2 to the need to have 'regard to the relevant provisions of other national instruments'.

\section{General Principles}

Article 2 Some groups of children are particularly vulnerable to economic exploitation. The Committee has repeatedly highlighted concerns, for example, over the 
abuse of girls in domestic labour (2016a, paras. 84-86), ${ }^{1}$ the exploitation of children with disabilities in begging and drug trafficking (2007a, para. 75), and the criminalisation of children in street situations leading to commercial sexual exploitation (2017b, para. 59). It urges States Parties to take appropriate actions to address these discriminatory vulnerabilities. Furthermore, children who do work should not suffer wage discrimination, for example, being forced to accept low wages that do not reflect their skills (UN Committee on Economic, Social and Cultural Rights, 2016, para. 47 (b)).

Article 3 While harmful or hazardous work is clearly not in the best interests of the child, the Committee has recognised that work can play a positive role, particularly in the lives of older children. It highlights the importance of a transitional approach towards balancing the role of work in the lives of adolescents while ensuring their other rights.

Article 6 Article 32 focuses on the right of the child to protection from any work that is harmful to their health or physical, mental, spiritual, moral, or social development, a broader requirement than that included in the ILO Conventions, which only address morals and health. States Parties are required to introduce all necessary measures to ensure that protection. However, the Committee recognises the positive developmental role of appropriate work, highlighting its potential for equipping them to learn skills, take responsibility, contribute to their families' well-being, and support their access to education (2003, paras. 18, 39 (e), 2016a, para. 85).

Article 12 The Committee emphasises that States Parties must ensure children are involved in the development of all relevant legislation and policies that affect their lives, a prescription that includes measures relating to child labour (2016a, para. 23). It specifically affirms that children, and where they exist, representatives of working children's organisations, should be heard when labour laws are drafted or when enforcement of laws is considered and evaluated (2009a, para. 117).

Although Article 15, the right to freedom of association and assembly, does not reference the right to join a trades union, the restrictions outlined in its paragraph 2 do not justify any prohibition on children from either forming their own or joining existing unions (UN Committee on the Rights of the Child, 2001, para. 38; Office of the United Nations High Commissioner for Human Rights and Rädda barnen (Society: Sweden), 2007, p. 469). Article 41, which stipulates that the standards of other international instruments should not be lowered by any provision in the Convention on the Rights of the Child, lends further weight to the argument that Article 15 should be interpreted to include the right of working children to trade union rights, to the same standard as that provided by the International Covenant on Civil and Political Rights (Daly, 2016, p. 35).

\footnotetext{
${ }^{1}$ See also, for example, concluding observations for Senegal (2006a, paras. 60-63), and Qatar (2017a, para. 35).
} 


\section{Articles Related or Linked to Article 32}

Article 11 deals with illicit transfer of children and includes the right to protection from trafficking.

Article 15 establishes the right of children to freedom of association, which includes the right to join and form trade unions or associations.

Article 19 asserts the right to protection from all forms of violence including within environments where children are working.

Article 24 addresses the right to the best possible health, and accordingly, children must not be exposed to work that is detrimental to their health and wellbeing.

Article 27 asserts that children have the right to a standard of living that is good enough to meet their physical and social needs and support their development.

Article 28 recognises the right to education, and children must not be involved in child labour that deprives them of that right.

Article 31 recognises rights to rest, play, leisure, and recreation and the arts, and these must not be compromised by the demands of children's involvement in work.

Article 33 recognises that children must not be used in the illicit production or trafficking of narcotic drugs.

Article 34 asserts that children must be protected from all forms of sexual exploitation and abuse.

Article 35 provides that children are entitled to protection from being sold, abducted or trafficked.

Article 38 provides protection for children affected by war and states that children under 15 must not be recruited into hostilities.

Article 39 requires that children who are exposed to harmful work must be entitled to recovery and reintegration.

Optional Protocol on sale of children, elaborates prohibitions on the sexual exploitation of children, and their use in any form of sexual activity for purposes of remuneration.

Optional Protocol on involvement of children in armed conflict, prohibits compulsory recruitment of children under 18 into armed forces and no recruitment into armed groups is acceptable under 18 years.

\section{Relevant Instruments}

Child labour has been addressed in many international treaties, dating back to the 1919 ILO Convention. Although many of the early ILO treaties remain in force, they have been largely superseded by later ILO Conventions, which are those most frequently referenced by the Committee on the Rights of the Child. ILO Conventions and other instruments most frequently referenced by the Committee include: 
- ILO Convention 138, Minimum Age (1973), consolidates earlier ILO Conventions dating back to 1919

- ILO Convention 182, Worst Forms of Child Labour (1999)

- ILO Declaration on Fundamental Principles and Rights at Work (1998), which includes the elimination of child labour as one of its four fundamental rights guaranteed to all as an immediate consequence of membership in ILO

- ILO Recommendation 146, Minimum Age (1973)

- ILO Recommendation 190, Worst Forms of Child Labour (1999)

In addition, the ILO Global Report 2002, A future without child labour, clarifies the boundaries of term child labour. It does not apply to all work but only that which violates international standards. It elaborates three categories of work to be abolished:

- Labour by a child under the minimum age prescribed in national legislation and in line with international standards

- Labour that jeopardises the physical, mental or moral well-being of child defined as hazardous work

- Worst forms of child labour which, are defined as slavery, trafficking, debt bondage, and other forced labour, forced recruitment for armed conflict, prostitution and pornography, and illicit activities.

Other Relevant Instruments:

- UN Universal Declaration of Human Rights (1948), Articles 4, 23, which state no one shall be held in slavery; everyone has the right to work, fair remuneration, and join a trades union.

- International Covenant on Civil and Political Rights (1966), Article 8, which requires no forced labour or servitude.

- International Covenant on Economic, Social and Cultural Rights (1966), Article 7, which elaborates the right to work and just and favourable conditions. It requires special measures of protection and assistance for children including from economic and social exploitation. Work harmful to morals or health or likely to damage their development should be punishable in law. It also recommends minimum age limits.

- African Charter on the Rights and Welfare of the Child (1990), Article 15, which spells out that provisions on economic exploitation apply to both formal and informal work, and explicitly refers to ILO Conventions.

- European Social Charter (Revised) (1996), Article 7, establishes detailed rights to protection at work for children.

- Additional Protocol to the American Convention on Human Rights in the Area of Economic, Social, and Cultural Rights 'Protocol of San Salvador' (1988), Article 7 , which prohibits night work or dangerous work for those under 18, and for all under 16, asserts that work must not impede full time education.

- Charter of Fundamental Rights of the European Union (2000), Article 32, which states that employment of children is prohibited, that minimum working age must 
correspond to school leaving age. And children must be protected from exploitation and harmful work or any work interfering with education.

\section{Attributes}

\section{Attribute One: Protection from Economic Exploitation and Harmful Work}

Article 32 establishes the right to protection from economic exploitation. It does not imply that all work is unacceptable. Rather, it sets out in general terms the nature of exploitative work from which children must be protected, including that which is hazardous (relating to an immediate or imminent danger), harmful to their development (applying to longer-term risks), or interferes with education. Such work has been defined as child labour by the ILO (n.d.), and has been described by the ILO as including (International Labour Organization, 2002):

- any work under the minimum age prescribed in national legislation or which fails to comply with the relevant protective standards

- hazardous work that jeopardises the physical, mental or moral well-being of a child

- the worst forms of child labour including slavery, trafficking, debt bondage, or other forced labour, forced recruitment for armed conflict, child sexual abuse and illicit activities (International Labour Organization, 1999, p. 182).

The Committee has emphasised the importance of adopting a holistic approach to child labour, addressing it in the context of the four General Principles (as above). It has made clear that work must be defined to cover both formal and informal activities, including, for example, domestic labour, agricultural work for the family, and street activities (International Labour Organization, 2006, p. 11; UN Committee on the Rights of the Child, 2000a, paras. 65-71). ${ }^{2}$

Building on ILO Convention 182 on the worst forms of child labour, the Committee has outlined in more detail the types of work that are prohibited and must be legislated against, including that which is contrary to the child's human dignity, cruel, inhuman or degrading, dangerous or harmful, discriminatory, below the minimum age, and that which involves legally punishable criminal activities (1994a, pp. 38-43). The Committee has highlighted a number of specific forms of child labour needing abolition including, for example, cotton-picking, mining, working on sugar cane plantations, working as a child jockey, and domestic labour for girls, the latter sometimes defined as a worst form of child labour under ILO

\footnotetext{
${ }^{2}$ See also, for example, concluding observations for Iran (2005a, para. 69) and Kenya (2016b, para. 71 (b)).
} 
182. ${ }^{3}$ Since ILO 182 was adopted in 1999 , the Committee has consistently referred States Parties to its standards and encouraged ratification and implementation. ${ }^{4}$

\section{Attribute Two: Regulatory Framework to Provide Protection}

Article 32 imposes on States Parties a requirement to introduce a regulatory framework prescribing ages and conditions of employment for children. In this regard, the Committee consistently recommends that States Parties ratify and implement ILO Convention 138 which elaborates the need to progressively raise the minimum age for work to a level consistent with physical and mental development, to define the work activities permitted, and prescribe the number of hours and conditions of work. ${ }^{5}$ The Committee, in line with ILO 138, regularly recommends the age of 15 years as the appropriate minimum age for full time work, and also presses for consistency between the minimum school leaving age and entry into full time employment as an added level of protection. ${ }^{6}$ However, the Committee emphasises that it is not the intention of Article 32 to prevent, for example, flexible engagement of children in seasonal work, nor to prohibit domestic chores, as long as these activities are consistent with receiving an education (1993, para. 44).

Consistent with its focus on a holistic approach to Article 32, the Committee has drawn States Parties attention to the need for legislation and regulation to protect other rights in the context of work. In addition to the importance of applying the General Principles, and the need to ensure the right to education and healthy development, it highlights reports from children of exposure to violence in the workplace as a means of coercion, punishment or control, and the imperative for explicit prohibition of corporal punishment in all work environments $(2007 \mathrm{~b}$, paras. 35-36). The Committee also emphasises the need for legal standards that afford children the opportunity to exercise their rights to rest, leisure, play and recreation under Article 31 (2013, para. 29).

\footnotetext{
${ }^{3}$ See, for example, concluding observations for Mongolia (2005b, paras. 60, 61), Uzbekistan (2006b, paras. 64, 65), Bolivia (2009b, para. 74), and Senegal (2006a, paras. 60-63), and Preliminary Observations: Colombia (1994b, para. 9).

${ }^{4}$ See, for example Concluding Observations: Korea (2017c).

${ }^{5}$ See, for example, Concluding Observations: Mongolia (2017d, para. 41).

${ }^{6}$ See, for example, concluding observations for Belarus (1994c) and Sri Lanka (1994d, para. 41).
} 


\section{Attribute Three: Administrative, Social, and Educational Measures for Protection}

Article 32 requires States Parties to go beyond the introduction of an appropriate legislative framework and to adopt administrative, social, and educational measures for protecting children from exploitative or harmful work. The introduction of age limits and prohibited forms of work will not address the problem of child labour without being undertaken in the context of wider measures. The Committee has recommended a range of approaches necessary to contribute to such protection:

- Disaggregated data collection to understand the dynamics of child labour and support recommendations that will address its the root causes and dangers ${ }^{7}$

- Investment in social and economic development and poverty eradication (2016a, para. 85)

- Universal free access to quality, inclusive primary and secondary education (2016a, para. 85)

- Coordination of schooling and introduction to decent work, with support for school-to-work transitions (2016a, para. 85)

- Family support programmes to eliminate child labour (2016c, para. 66 (e))

- Establishing and strengthening monitoring capacity at government and local levels to identify children engaged in the worst forms of child labour and ensure their removal, rehabilitation and reintegration (2017e, para. 43 (a))

- Awareness-raising programmes, including campaigns, targeting children and their parents on the rights of working children (2016d, para. 44 (d))

- Co-operation with the International Programme on the Elimination of Child Labour ILO/IPEC (2006c, paras. 67-68).

\section{Attribute Four: Penalties and Enforcement for Effective Protection}

States Parties are required to introduce mechanisms for effective enforcement of measures to protect children under their Article 32 rights. This includes a regulatory framework establishing responsibilities for compliance in both the formal and non-formal sectors which must be reinforced by a trained labour inspectorate, backed up with the necessary support and appropriate penalties in cases of non-compliance (UN Committee on the Rights of the Child, 2006d, para. 89).

The Committee encourages awareness raising among the public of the legal protections against exploitation of child labour with a view to encouraging the reporting of violations and ensuring these are thoroughly investigated and

\footnotetext{
${ }^{7}$ See, for example, concluding observations for South Africa (2000b, para. 14) and Peru (2016c, para. $66(\mathrm{~g}))$.
} 
perpetrators are sanctioned (2017f, para. 43 (c)). However, it is imperative that interventions designed to protect children are not undertaken in a manner that undermines protection, for example, criminalising children and resulting in engagement in more harmful and less regulated work. Dialogue with children on the most appropriate means of providing protection, together with community engagement, is essential. $^{8}$

\section{References}

Daly, A. (2016). A commentary on the United Nations convention on the rights of the child, article 15: The right to freedom of association and to freedom of peaceful assembly. A commentary on the United Nations Convention on the Rights of the Child, Article 15: The right to freedom of association and to freedom of peaceful assembly. Brill Nijhoff. Retrieved October 24, 2020, from https://brill.com/view/title/11631

International Labour Organization. (1999). Convention C182 - worst forms of child labour convention, 1999 (no. 182). Geneva: ILO. Retrieved November 26, 2020, from https://www.ilo.org/ dyn/normlex/en/f?p=NORMLEXPUB:12100:0::NO::P12100_ILO_CODE:C182

International Labour Organization. (2002). A future without child labour. Global report under the follow-up to the ILO Declaration on Fundamental Principles and Rights at Work. Report of the Director-General, 2002 (Report). Retrieved November 26, 2020, from http://www.ilo.org/ global/publications/ilo-bookstore/order-online/books/WCMS_PUBL_9221124169_EN/lang\% 2D\%2Den/index.htm

International Labour Organization. (2006). The end of child labour: Within reach. Geneva. Retrieved December 20, 2020, from https://www.ilo.org/ipec/Informationresources/WCMS_ IPEC_PUB_2419/lang\%2D\%2Den/index.htm

International Labour Organization. (n.d.). IPEC - What is child labour. International Programme on the Elimination of Child Labour. Retrieved November 26, 2020, from https://www.ilo.org/ipec/ facts/lang\%2D\%2Den/index.htm

Office of the United Nations High Commissioner for Human Rights \& Rädda barnen (Society: Sweden). (2007). Legislative history of the convention on the rights of the child. New York: United Nations. Retrieved from https://digitallibrary.un.org/record/602462? $\mathrm{ln}=\mathrm{en}$

Swepston, L. (2012). A commentary on the United Nations convention on the rights of the child, article 32: Protection from economic exploitation. A commentary on the United Nations convention on the rights of the child, article 32: Protection from economic exploitation. Brill Nijhoff. Retrieved November 26, 2020, from https://brill.com/view/title/11644

The Concerned for Working Children. (n.d.). Child work and child labour. The concerned for working children. Retrieved November 26, 2020, from http://www. concernedforworkingchildren.org/empowering-children/child-work-and-child-labour/

UN Committee on Economic, Social and Cultural Rights. (2016). ICESCR General Comment No. 23 (2016) on the right to just and favourable conditions of work, E/C.12/GC/23. UN. Retrieved November 26, 2020, from http://digitallibrary.un.org/record/1312521

UN Committee on the Rights of the Child. (1993). Summary record of the 68th meeting, held at the Palais des Nations, Geneva, on Tuesday, 26 January 1993 (Concluding observations: Egypt). UN. Retrieved November 26, 2020, from http://digitallibrary.un.org/record/164601

UN Committee on the Rights of the Child. (1994a). Report on the 5th session, 10-28 January 1994, CRC/C/24. Retrieved October 12, 2020, from https://digitallibrary.un.org/record/193291?ln=en

\footnotetext{
${ }^{8}$ See, for example, 'Child work and child' (The Concerned for Working Children, n.d.)
} 
UN Committee on the Rights of the Child. (1994b). Preliminary observations: Colombia, February 7, 1994, CRC/C/15/Add.15. UN. Retrieved November 26, 2020, from http://digitallibrary.un. org/record/197663

UN Committee on the Rights of the Child. (1994c). Concluding observations: Belarus, February 7, 1994, CRC/C/15/Add.17. UN. Retrieved November 26, 2020, from http://digitallibrary.un. org/record/197665

UN Committee on the Rights of the Child. (1994d). Concluding observations: Sri Lanka, June 21, 1994, CRC/C/15/Add.40. Retrieved November 6, 2020, from https://digitallibrary.un.org/ record $/ 191817 ? \mathrm{ln}=\mathrm{en}$

UN Committee on the Rights of the Child. (2000a). Concluding observations: India, February 23, 2000, CRC/C/15/Add.115. Retrieved October 11, 2020, from https://digitallibrary.un.org/ record $/ 412551 ? \mathrm{ln}=\mathrm{en}$

UN Committee on the Rights of the Child. (2000b). Concluding observations: South Africa, February 22, 2000, CRC/C/15/Add.122. UN. Retrieved November 26, 2020, from http:// digitallibrary.un.org/record/414198

UN Committee on the Rights of the Child. (2001). Concluding observations: Turkey, July 9, 2001, $C R C / C / 15 / A d d .152$. Retrieved October 23, 2020, from https://digitallibrary.un.org/record/ $451935 ? \ln =\mathrm{en}$

UN Committee on the Rights of the Child. (2003). General Comment No. 4 (2003) Adolescent health and development in the context of the Convention on the Rights of the Child, July 1, 2003, $C R C / G C / 2003 / 4$. Retrieved October 12, 2020, from https://digitallibrary.un.org/record/503074? $\ln =\mathrm{en}$

UN Committee on the Rights of the Child. (2005a). Concluding observations: Iran, March 31, 2005, CRC/C/15/Add.254. Retrieved October 12, 2020, from https://digitallibrary.un.org/ record $/ 557400 ? \mathrm{ln}=$ en

UN Committee on the Rights of the Child. (2005b). Concluding observations: Mongolia, September 21, 2005, CRC/C/15/Add.264. UN. Retrieved November 26, 2020, from http:// digitallibrary.un.org/record/570464

UN Committee on the Rights of the Child. (2006a). Concluding observations: Senegal, October 20, 2006, CRC/C/SEN/CO/2. UN. Retrieved November 26, 2020, from http://digitallibrary.un. $\mathrm{org} / \mathrm{record} / 589674$

UN Committee on the Rights of the Child. (2006b). Concluding observations: Uzbekistan, June 2, 2006, $C R C / C / U Z B / C O / 2$. UN. Retrieved November 26, 2020, from http://digitallibrary.un. org/record $/ 594828$

UN Committee on the Rights of the Child. (2006c). Concluding observations: Benin, October 20, 2006, $C R C / C / B E N / C O / 2$. UN. Retrieved November 26, 2020, from http://digitallibrary.un. org/record/589640

UN Committee on the Rights of the Child. (2006d). Concluding observations: Jordan, November 1, 2006, CRC/C/JOR/CO/3. UN. Retrieved November 26, 2020, from http://digitallibrary.un. org/record/589751

UN Committee on the Rights of the Child. (2007a). General Comment No. 9 (2006) The rights of children with disabilities, November 13, 2007, CRC/C/GC/9. Retrieved October 12, 2020, from https://digitallibrary.un.org/record/593891? $\mathrm{ln}=\mathrm{en}$

UN Committee on the Rights of the Child. (2007b). General Comment No. 8 (2006) The right of the child to protection from corporal punishment and other cruel or degrading forms of punishment (arts. 19; 28, para. 2; and 37, inter alia), March 2, 2007, CRC/C/GC/8. Retrieved October 12, 2020, from https://digitallibrary.un.org/record/583961? ln=en

UN Committee on the Rights of the Child. (2009a). General Comment No. 12 (2009) The right of the child to be heard, July 20, 2009, CRC/C/GC/12. Retrieved October 12, 2020, from https:// digitallibrary.un.org/record/671444? $\mathrm{ln}=\mathrm{en}$

UN Committee on the Rights of the Child. (2009b). Concluding observations: Bolivia, October 16, 2009, CRC/C/BOL/CO/4. UN. Retrieved December 20, 2020, from http://digitallibrary.un. org/record/668535 
UN Committee on the Rights of the Child. (2013). General Comment No. 17 (2013) on the right of the child to rest, leisure, play, recreational activities, cultural life and the arts (art. 31), April 17, 2013, $C R C / C / G C / 17$. Retrieved October 12, 2020, from https://digitallibrary.un.org/record/ $778539 ? \ln =\mathrm{en}$

UN Committee on the Rights of the Child. (2016a). General Comment No. 20 (2016) on the implementation of the rights of the child during adolescence, December 6, 2016, CRC/C/GC/20. Retrieved October 12, 2020, from https://digitallibrary.un.org/record/855544? ln=en

UN Committee on the Rights of the Child. (2016b). Concluding observations: Kenya, March 21, 2016, CRC/C/KEN/CO/3-5. UN. Retrieved November 14, 2020, from http://digitallibrary. un.org/record/834997

UN Committee on the Rights of the Child. (2016c). Concluding observations: Peru, March 2, 2016, $C R C / C / P E R / C O / 4-5$. UN. Retrieved November 26, 2020, from http://digitallibrary.un.org/ record $/ 834928$

UN Committee on the Rights of the Child. (2016d). Concluding observations: New Zealand, October 21, 2016, CRC/C/NZL/CO/5. UN. Retrieved November 6, 2020, from http:// digitallibrary.un.org/record/856035

UN Committee on the Rights of the Child. (2017a). Concluding observations: Qatar, June 22, 2017, CRC/C/QAT/CO/3-4. UN. Retrieved November 22, 2020, from http://digitallibrary. un.org/record/1311379

UN Committee on the Rights of the Child. (2017b). General Comment No. 21 (2017) on children in street situations, June 21, 2017, CRC/C/GC/21. Retrieved October 12, 2020, from https:// digitallibrary.un.org/record/1304490? $\mathrm{ln}=\mathrm{en}$

UN Committee on the Rights of the Child. (2017c). Concluding observations: Korea, October 23, 2017, CRC/C/PRK/CO/5. UN. Retrieved November 26, 2020, from http://digitallibrary.un. org/record/1311397

UN Committee on the Rights of the Child. (2017d). Concluding observations: Mongolia, July 12, 2017, CRC/C/MNG/CO/5. UN. Retrieved November 26, 2020, from http://digitallibrary.un. org/record/1311385

UN Committee on the Rights of the Child. (2017e). Concluding observations: Tajikistan, October 25, 2017, CRC/C/TJK/CO/3-5. UN. Retrieved November 7, 2020, from http://digitallibrary.un. org/record/1311398

UN Committee on the Rights of the Child. (2017f). Concluding observations: Cameroon, July 6, 2017, CRC/C/CMR/CO/3-5. UN. Retrieved November 22, 2020, from http://digitallibrary.un. org/record/1311383

Open Access This chapter is licensed under the terms of the Creative Commons Attribution 4.0 International License (http://creativecommons.org/licenses/by/4.0/), which permits use, sharing, adaptation, distribution and reproduction in any medium or format, as long as you give appropriate credit to the original author(s) and the source, provide a link to the Creative Commons license and indicate if changes were made.

The images or other third party material in this chapter are included in the chapter's Creative Commons license, unless indicated otherwise in a credit line to the material. If material is not included in the chapter's Creative Commons license and your intended use is not permitted by statutory regulation or exceeds the permitted use, you will need to obtain permission directly from the copyright holder.

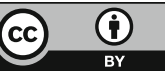

